\title{
DEVELOPMENT OF E-GOVERNMENT IN BOSNIA AND HERZEGOVINA
}

\author{
Zvezdan Stojanović ${ }^{1}$ \\ Mehrudina Musić
}

\author{
Original scientific paper
}

European University Kallos, Tuzla, Bosnia and Herzegovina

Received:13.11.2017

Accepted:15.02.2018

\begin{abstract}
Effective collaboration between all level of government (on local and state level), all agencies and ministries have great impact on development one country. Here is reflected the importance of the introduction of e-government, which should effectively connect all of those participants into one efficient unit. Bosnia and Herzegovina is country with complicated political and terrestrial order with two entities and one district and with ten cantons in one entity. It is main reason why Bosnia and Herzegovina has uneven development of e-Government. In this article, we will give an overview of the situation in Bosnia and Herzegovina regarding ICT and we will make a comparison of the situation in BiH in terms of development of e-government with the neighboring countries.
\end{abstract}

Keywords: e-government, ICT infrastructure, legislation

\section{INTRODUCTION}

Technology development, especially using information-communications technologies (ICT), Internet, mobile phones and digital television transformed functioning of government. Most governments around the world distribute information through their websites, build their digital databases, and increasingly allow citizens to provide online services using the Internet (UN, 2014).

Today, in literature, e-Government and e-Governance are terms, used interchangeable. In (ITU,
2008) is made differences between them. "E-Government focuses on the utilization of information and communication technologies (ICT) to deliver e-government services. Term e-Governance characterizes effort to use ICT for political purposes and the organization of political activity in a country".

Essentially, this is a new way of governing, by which the state administration focuses its business towards the needs of citizens and the economy, all with the help of modern information and communication technologies.

\footnotetext{
$\overline{{ }^{1} \text { Correspondence to: }}$

Zvezdan Stojanovic, associate professor, Mehrudina Musić, dipl. ing. Department of Information Technology, European University Kallos

Maršala Tita 2A-2B, 75000 Tuzla, Bosnia and Herzegovina

Phone: +38735299091

E-mail:zvezdan.stojanovic070@gmail.com; mehrudina.music82@gmail.com
} 


\section{ADVANTAGES AND DISADVENTAGES OF e- GOVERNMENT}

By introducing e-government, the provision of information and services to the users is significantly improved, and in addition, which is very important, it facilitates and encourages the participation of citizens and legal entities in decision-making processes. In this way, the time of collection, processing and transfer of data reduced, it achieves greater transparency, accountability and efficiency of the work of the administration, and the whole business directed towards the users. Efficient public services can result in significant cost savings, or the development of new kinds of services at the same cost. In 2012, the European Commission estimated that all EU public administrations using e-procurement procedures could save at least $€ 100$ billion per year and that egovernment could reduce costs by 15 to $20 \%$, (European Parliament, 2015).

In (Protopappas \& Sideridis, 2013), using e-Government services is considered as a way to eliminate corruption because mediators between citizens and service providers are abolished.

The use of e-Government services brings benefits to both the administration and the citizens. In regard of administration, this is reflected in the increased speed of service provision to citizens, as there is a reduction in waiting time in queues because citizens can now access e-Government services both from home or through their mobile phones. This will lead to increased citizen's satisfaction, because the implementation of e-Government services will lead to faster and cheaper performance of services. When developing the e-Government services, it must be careful that there are still a significant number of citizens without enough technical skills and often no desire to apply something new. Data used by citizens when using certain services at the request of the administration are later entered into different digital databases and information system of the administration, and these data are again used in the access of citizens to other administrative services. This data helps the administration to create more personalized services, but the citizens can't be sure that these data will not be misused. On-line payment of e-Government services for one significant part of the population continues to raise doubts as to the security of transactions.

\section{SERVICES OF e-GOVERNMENT}

E-government users can be classified into the following categories:G-Government, E-Employee, B-Business, CCitizen.

By interacting between them, the following categories of e-government are created (Figure 1):

- government-to-citizens (G2C): includes all the interactions between a government and its citizens,

- government-to-business (G2B): includes interactions between government and businesses,

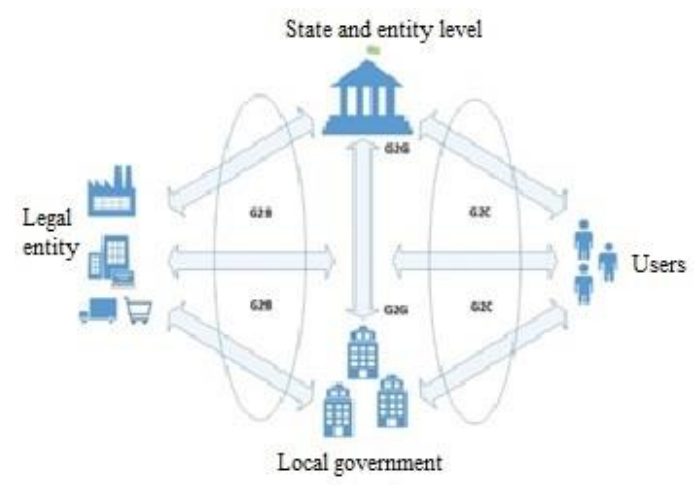

Figure 1. Categories of e-government

- government-to-government (G2G): includes activities within government units (state level, entities level and between entities),

- government-to-employees (G2E): includes activities between government units and their employees (Stojanović, 2014).

Table 1 Services for the public sector and business

\begin{tabular}{|c|c|}
\hline Public services for citizens & $\begin{array}{c}\text { Public services for } \\
\text { businesses }\end{array}$ \\
\hline $\begin{array}{l}\text { 1. Income taxes: } \\
\text { declarations, notifications } \\
\text { of assessment }\end{array}$ & $\begin{array}{l}\text { 1. Social contributions } \\
\text { for employees }\end{array}$ \\
\hline 2. Job search services & $\begin{array}{l}\text { 2. Corporation tax: } \\
\text { declaration, } \\
\text { notification }\end{array}$ \\
\hline $\begin{array}{l}\text { 3. Social security: } \\
\text { - unemployment } \\
\text { benefits } \\
\text { - medical costs }\end{array}$ & $\begin{array}{l}\text { 3. VAT: declaration, } \\
\text { notification }\end{array}$ \\
\hline $\begin{array}{l}\text { 4. Personal documnets } \\
\text { (passport or driver's } \\
\text { licences) }\end{array}$ & $\begin{array}{l}\text { 4. Registration of a new } \\
\text { company }\end{array}$ \\
\hline 5. Car registration & $\begin{array}{l}\text { 5. Submission of data to } \\
\text { statistical offices }\end{array}$ \\
\hline $\begin{array}{l}\text { 6. Application for building } \\
\text { permission }\end{array}$ & 6. Customs declarations \\
\hline 7. Declaration to the police & $\begin{array}{l}\text { 7. Environment-related } \\
\text { permits }\end{array}$ \\
\hline 8. Public libraries & 8. Public procurement \\
\hline $\begin{array}{l}\text { 9. Certificates (birth, } \\
\text { marriage) }\end{array}$ & \\
\hline $\begin{array}{l}\text { 10. Enrolment in higher } \\
\text { educations }\end{array}$ & \\
\hline $\begin{array}{l}\text { 11. Announcement of } \\
\text { moving (chage address }\end{array}$ & \\
\hline 12. Health related services & \\
\hline
\end{tabular}


The European Commission set up a set of 20 basic electronic services: 12 services for the public sector, and 8 services for the business, (Commission of the European Communities, 2015).

\section{OVERVIEW ON SITUATION IN BOSNIA AND HERZEGOVINA}

Bosnia and Herzegovina $(\mathrm{BiH})$ is a transitional economy which is pursuing membership in the European Union and the World Trade Organization.

From the wars of the nineties, $\mathrm{BiH}$ came out with a devastated economy whose current level of de- velopment best illustrates BiH's position in the WEF's (World Economic Forum) annual report for 2016/2017. WEF defined competitiveness of the countries as "set of institutions, policies, and factors that determine the level of productivity of an economy in its "Global Competitiveness Report (GCI)" (Schwab, 2016).

It estimates a number of indicators as it can be seen in Fig 1. Report for 2016/2017 year covers 138 economies and $\mathrm{BiH}$ is on the 107 position in it. In this Report, we can see state of the countries in seroundings. Croatia is in the 74th position, Montenegro in the 82th and Serbia in the 90th.

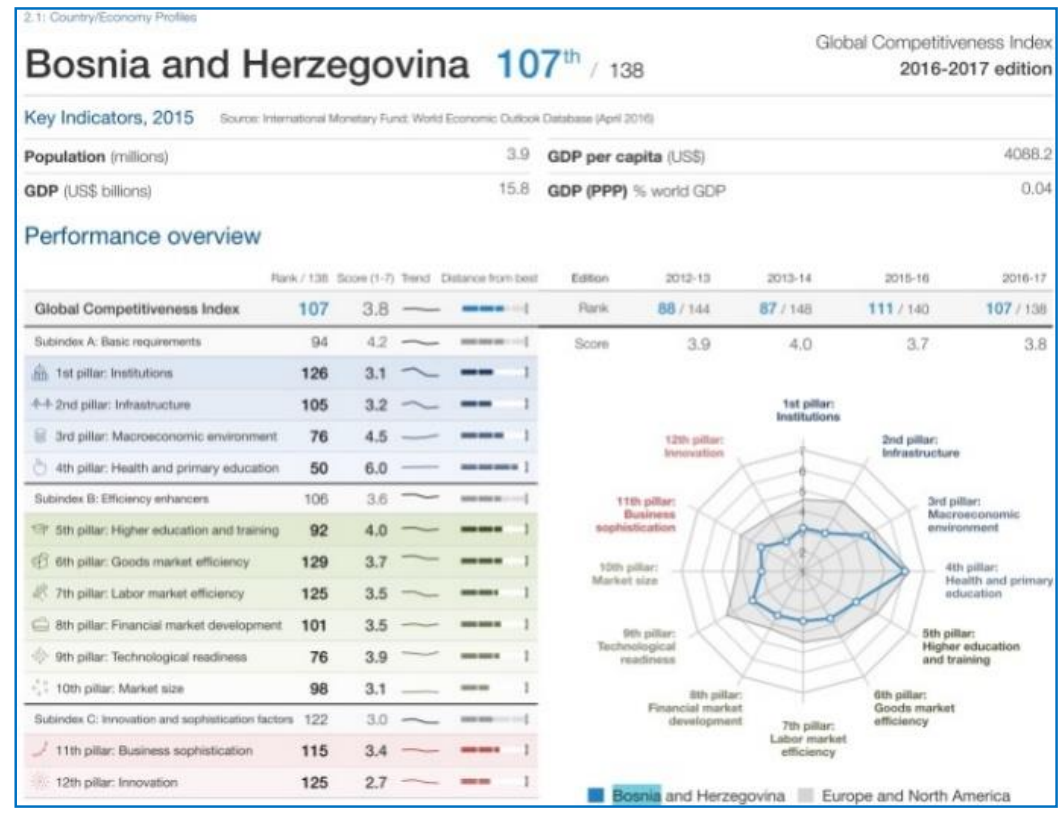

Figure 2.GCI for BiH

The level of economic development has a large, but not decisive, impact on the development of e-Government. In (UN, 2016), it can be seen that "There are many countries that have significantly advanced their e-government despite relatively low national income, just as there are many countries which are lagging behind despite their relatively high income".

\section{ICT infrastructure in $\mathrm{BiH}$}

In accordance by International Telecommunications Union (ITU, 2015), key ICT indicators for developed and developing countries are: penetration rates for fixed, mobile and Internet subscribers, (CRA, 2014).

In Report (UNDP, 2010) is also considered at those three key indicators and they are compared to different countries of Southeast Europe, but this report looks at more two important indicators which can be used to determine the availability of e-Government services:

- the percentage of government institutions that use some form of networking services;

- the percentage of government institutions that are connected to the Internet.

Number of pupils per computer (in primary and secondary schools) is used also as indicator of the level of a country's investment in ICT infrastructure in this Report (UNDP, 2010).

Communication Regulatory Agency (CRA) in BiH collects data from the all operators in $\mathrm{BiH}$ and performs their processing and analysis. 

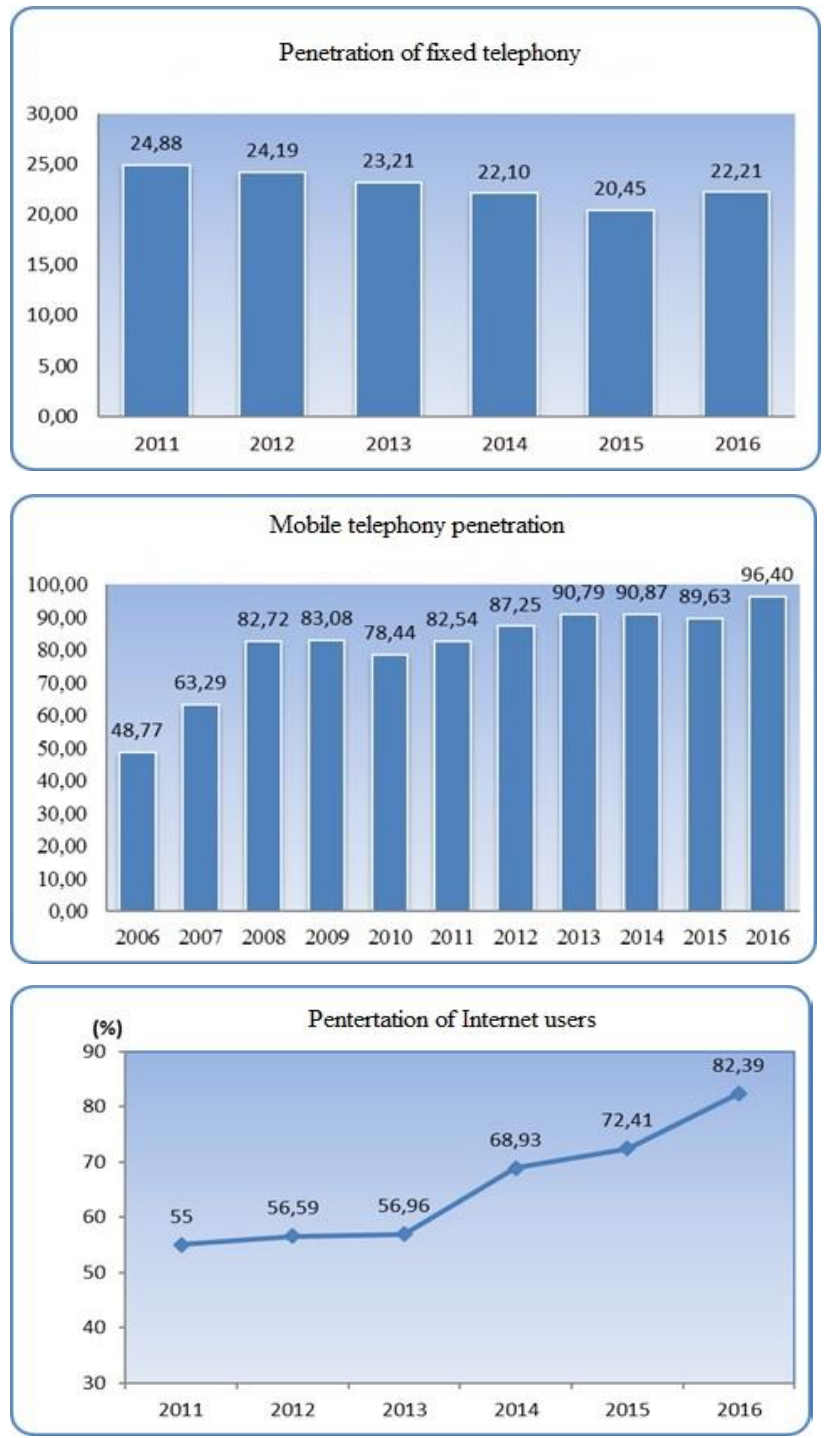

Figure 3. ICT indicators in BiH

ICT indicators for $\mathrm{BiH}$ (based on CRA reports) are shown in Figure 3.

New services require high speeds and it is therefore important that access networks are broadband.

The use of broadband Internet access in Bosnia and Herzegovina is constantly on the rise, as evidenced by the fact that the degree of use of broadband access for the level of Bosnia and Herzegovina (the number of connections compared to the total population) is $18.76 \%$, (CRA, 2017).

\section{Legislation for e-Government in $\mathrm{BiH}$}

Appropriate legal framework is needed to regulate the relationship between citizens, business and legal entities on the one side and the state (state bodies and civil servants) on the other side in the use of ICT.
Legal regulation of e-government should create clear rules for all previously listed relationships: G2C, $\mathrm{G} 2 \mathrm{~B}, \mathrm{G} 2 \mathrm{G}$ and $\mathrm{G} 2 \mathrm{E}$ in the use of information and communication technologies.

In accordance with the Dayton Peace Agreement, the state-level government is weak and has limited jurisdiction over the adoption and implementation of public policies. Bosnia and Herzegovina consists of the two entities - the Federation of $\mathrm{BiH}(\mathrm{FBiH})$ and Republika Srpska (RS), and the Brcko District as a separate administrative unit of local self-government. The $\mathrm{FBiH}$ is divided in ten cantons and additionally includes 80 units of local self-government (78 municipalities and two towns), and RS 63 (61 municipalities and two towns). The state level has no authority over the issues of local self-government, (Čurčić \& Hodžić, 2011).

Entity authority is the competent in the RS for local self-government. In $\mathrm{FBiH}$ the competence for local self-government is on the entity and cantonal level and main problem is in the fact that the cantons compete with local governments for the jurisdiction.

At the state level, the Law on the Information Society Agency has not yet been adopted. One of the most strategically important projects at the state level was the introduction of a system for issuing personal documents called CIPS (Citizen Identification Protection System). The legal successor of this project is the Agency for Identification Documents, Records and Data Exchange of Bosnia and Herzegovina.

However, while the $\mathrm{FBiH}$ relies exclusively on the laws adopted at the state level, whose adoption is very slow, the RS has already adopted a whole set of laws and by-laws related to e-government.

RS was created Agency for Information Society of Republika Srpska (AIDRS) with responsibility of development and coordination of the development of the Information Societies in the RS.

AIDRS is working on proposing and implementing measures for the construction of information systems of local self-government bodies, ensuring communication with republic authorities and applying unified software solutions as much as possible, as well as coordinating the establishment of a single database of state authorities and local government bodies in the RS.

The RS has adopted the strategic document "The Strategy of Electronic Government Development for the Period 2009-2015" and formed a body for monitoring the implementation of the strategy. 
At the RS level, the web portal of the public administration of the Republika Srpska -eSrpska (www.esrpska.org) is made.

At the RS level the following laws were adopted:

- Law on Electronic Signature of the RS ${ }^{2}$,

- Law on Electronic Document of $\mathrm{RS}^{3}$,

- Law on Electronic Business of $\mathrm{RS}^{4}$,

- Law on Information Security of $\mathrm{RS}^{5}$,

as well as by-low:

- Rulebook on Information Security Standards,

- Regulation on Information Security Measure,

- Rules on the records of certification bodies

- Registration policy certification,

- Rulebook on Electronic Signature and Qualified Electronic Signature Protection Measures, minimum amount of compulsory insurance and application of organized and consolidated text,

- Rulebook on technical rules for ensuring the connection of records of issued and revoked certificates of certification bodies in RS.

There are only a few documents on the state level like:

1. Law on electronic signature ${ }^{6}$,

2. Law on Electronic and legal business traffic ${ }^{7}$,

3. Regulations on access to records and data exchange ${ }^{8}$.

The FBiH relies mainly on state-level laws.

\section{Comparison development of e-Government with its surroundings countries}

Goal of E-Government Survey (produced every two year) is to give an indicative assessment of the diffusion of e-government through a performance rating of national governments relative to one another, (UN, 2016).

"Conceptual framework of the United Nations EGovernment Survey has adopted a holistic view of e-government development resting on three important dimensions: (i) the availability of online services (Online Service Component-OSI), (ii) telecommunication infrastructure (Telecommunication Infrastructure Index-TII) and (iii) human capacity (Human Capital Index-HCI)", (UN, 2016).
Where is $\mathrm{BiH}$ in comparison with the rest of the world in term of e-government development and its neighboring countries?

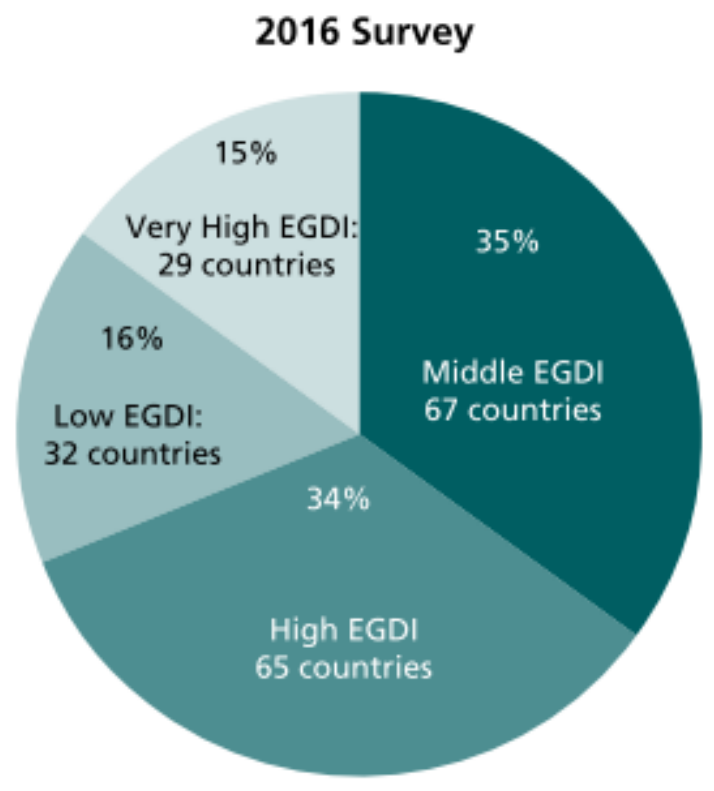

Figure 4. Number of countries grouped by EGovernment Development Index (EGDI)

$\mathrm{BiH}$ belong to the countries with high E-government development Index (EGDI) with EGDI value between 0,5 and 0,75 as it can be seen in Fig. 4 .

This is a big improvement from the 2014 report when Bosnia belonged to a group of the countries with a medium EDGE index, (UN, 2014).

Data for $\mathrm{BiH}$ and for countries in $\mathrm{BiH}$ neighbourhood are summarized in Tables 2, 3 and 4. The three previously mentioned components (OSI, TII and HCI) are considered.

${ }^{2}$ Official Gazette RS No, 106/15

${ }^{3}$ Official Gazette RS No, 106/15

${ }^{4}$ Official Gazette RS No, 59/09

${ }^{5}$ Official Gazette RS No, 70/11

${ }^{6}$ Official Gazette BiH, No, 91/2006

${ }^{7}$ Official Gazette No, 88/2007

${ }^{8}$ Official Gazette No, 35/2009 
Table 2 E-government development Index (EGDI)

\begin{tabular}{cccccc}
\hline Rank & Country & EGDI & $\begin{array}{c}\text { Online Service } \\
\text { Component (OSI) }\end{array}$ & $\begin{array}{c}\text { Telecomm. Infrastructure } \\
\text { Index (TII) }\end{array}$ & $\begin{array}{c}\text { Human Capital } \\
\text { Index (HCI) }\end{array}$ \\
\hline 37 & Croatia & 0,7162 & 0,7464 & 0,5974 & 0,8050 \\
39 & Serbia & 0,7131 & 0,8188 & 0,5434 & 0,7769 \\
45 & Monte Negro & 0,6733 & 0,6812 & 0,5221 & 0,8165 \\
92 & Bosnia and & 0,5118 & 0.4493 & 0.4047 & 0.6815 \\
& Herzegovina & & & & \multirow{2}{*}{. } \\
\hline
\end{tabular}

Table 3 Telecommunication Infrastructure Index (TII) and its components

\begin{tabular}{|c|c|c|c|c|c|c|}
\hline Country & TII & $\begin{array}{l}\text { Percentage of } \\
\text { individuals } \\
\text { using the } \\
\text { Internet }\end{array}$ & $\begin{array}{l}\text { Fixed/telephone } \\
\text { subscription per } \\
100 \text { inhabitants }\end{array}$ & $\begin{array}{c}\text { Mobile- } \\
\text { cellular } \\
\text { telephone } \\
\text { subscription } \\
\text { per } 100 \\
\text { inhabitants }\end{array}$ & $\begin{array}{l}\text { Fixed (wired) } \\
\text { broadband } \\
\text { subscription } \\
\text { per } 100 \\
\text { inhabitants }\end{array}$ & $\begin{array}{l}\text { Wireless broadband } \\
\text { subscriptions per } 100 \\
\text { inhabitants }\end{array}$ \\
\hline Croatia & 0.5974 & 68.57 & 37.72 & 104.43 & 23.04 & 66.10 \\
\hline Serbia & 0.5434 & 53.50 & 37.33 & 122.13 & 15.57 & 55.70 \\
\hline Monte Negro & 0.5221 & 61.00 & 26.49 & 163.03 & 15.20 & 23.10 \\
\hline $\begin{array}{l}\text { Bosnia and } \\
\text { Herzegovina }\end{array}$ & 0.4047 & 60.80 & 22.20 & 91.28 & 14.15 & 23.90 \\
\hline
\end{tabular}

Table 4 Human Capital Index (HCI)

\begin{tabular}{|c|c|c|c|c|c|c|c|c|c|c|c|c|c|}
\hline \multirow[t]{5}{*}{ Country } & \multirow[t]{5}{*}{$\mathrm{HCI}$} & \multicolumn{3}{|c|}{ Adult literacy (\%) } & \multicolumn{3}{|c|}{$\begin{array}{l}\text { Gross enrolment ratio } \\
(\%)\end{array}$} & \multicolumn{3}{|c|}{$\begin{array}{l}\text { Expected years of } \\
\text { schooling }\end{array}$} & \multicolumn{3}{|c|}{$\begin{array}{l}\text { Mean years of } \\
\text { schooling }\end{array}$} \\
\hline & & \multirow{4}{*}{$\begin{array}{l}\text { Index } \\
\text { value }\end{array}$} & \multirow[t]{2}{*}{ Y } & \multirow[t]{4}{*}{ Source } & \multirow{4}{*}{$\begin{array}{l}\text { Index } \\
\text { value }\end{array}$} & \multirow{4}{*}{$\begin{array}{l}\text { Ye } \\
\text { ar }\end{array}$} & \multirow[t]{4}{*}{ Source } & \multirow{4}{*}{$\begin{array}{l}\text { Index } \\
\text { value }\end{array}$} & Y & \multirow[t]{4}{*}{ Source } & \multirow{4}{*}{$\begin{array}{l}\text { Index } \\
\text { value }\end{array}$} & \multirow{4}{*}{$\begin{array}{c}\text { Ye } \\
\mathrm{a} \\
\mathrm{r}\end{array}$} & \multirow[t]{4}{*}{ Source } \\
\hline & & & & & & & & & $\mathrm{e}$ & & & & \\
\hline & & & $\mathrm{a}$ & & & & & & $\mathrm{a}$ & & & & \\
\hline & & & $\mathrm{r}$ & & & & & & $\mathrm{r}$ & & & & \\
\hline \multirow[t]{2}{*}{ Croatia } & 0.8050 & 99.27 & 201 & UNESC & 86.47 & 20 & UNESC & 14.81 & 20 & UNESC & 11.03 & 20 & UNESC \\
\hline & & & 5 & $\mathrm{O}$ & & 12 & $\mathrm{O}$ & & 12 & $\mathrm{O}$ & & 11 & $\mathrm{O}$ \\
\hline \multirow[t]{2}{*}{ Serbia } & 0.7769 & 98.11 & 201 & UNESC & 83.55 & 20 & UNESC & 14.39 & 20 & UNESC & 10.46 & 20 & UNESC \\
\hline & & & 5 & $\mathrm{O}$ & & 13 & $\mathrm{O}$ & & 13 & $\mathrm{O}$ & & 11 & $\mathrm{O}$ \\
\hline Monte & 0.8165 & 98.73 & 201 & UNESC & 88.62 & 20 & UNESC & 15.18 & 20 & UNESC & 11.16 & 20 & UNESC \\
\hline Negro & & & 5 & $\mathrm{O}$ & & 10 & $\mathrm{O}$ & & 10 & $\mathrm{O}$ & & 11 & $\mathrm{O}$ \\
\hline \multirow[t]{2}{*}{$\mathrm{BiH}$} & 0.6815 & 98.48 & 201 & UN- & 71.00 & 20 & UN- & 13.60 & 20 & UNDP & 7.21 & 20 & UN- \\
\hline & & & 5 & ESCO & & 14 & ESCO & & 12 & & & 11 & ESCO \\
\hline
\end{tabular}


BEST EXAMPLES OF e-GOVERNMENT SERVICES IN BIH

Most municipalities in Bosnia and Herzegovina use software that increase efficiency in different areas, such as registries $(99.7 \%)$, citizen registration software $(87.7 \%)$, as well as software for registering cadastral properties $(47.4 \%)$ and software for records social benefits.

Most municipalities have their own website and most use social networks like Facebook to inform citizens (Čurčić \& Hodžić, 2011).

The best examples of e-Government services in the Federation of the Bosnia and Herzegovina are:

- Web site of the Institute of Health Insurance and Reinsurance Fund of Federation of Bosnia and Herzegovina $^{9}$

- Web site of the Federal Administration for Geodetic and Property Relations ${ }^{10}$

- Web site of the Tax Administration Federation of Bosnia and Herzegovina ${ }^{11}$

The best examples of the e-Government services in the Republic of Serbs:

- Web site of the Health Insurance fund of Republika Srpska ${ }^{12}$

- Web site of the Electronic Land Registry of the Republika Srpska ${ }^{13}$

- Web site of the Tax Administration Republika Srpska $^{14}$

- Web portal of the public administration of the Republika Srpska ${ }^{15}$.

\section{CONCLUSION}

Bosnia and Herzegovina has a solid informationtelecommunication infrastructure, but development of e-Government slows down the harmonization and adoption of laws and by-laws that are important for development of e-Government on the state level.
The basic limiting factor in the development of egovernment is the lack of a political agreement on the further development of e-government, which should be followed by the adoption of appropriate laws.

But, comparing United Nations reports from 2014 and 2016, we can come to still encouraging conclusions: Bosnia and Herzegovina, despite all the difficulties it faces, made a certain shift in this field.

\section{REFERENCES}

Commission of the European Communities, (2001). A Communication to the Spring European Council in Stockholm.

CRA, (2017). The Annual Report of the communication regulatory agency for 2016, Sarajevo.

CRA, The Annual Survey of CRA License Holders for Providing Internet Services in Bosnia and Herzegovina for 2013, (2014). Sarajevo

European Parliament, (2015). eGovernment: Using technology to improve public services

Čurčić F, and Hodžić S, (2011). Razvoj lokalne e-uprave u Bosni $i$ Hercegovini, Sarajevo.

ITU, (2008). Electronic Government for Developing Countries

ITU, (2015). Key ICT indicators for developed and developing countries and the world (totals and penetration rates

Schwab, K. (2016). The Global Competitiveness Report, World Economic Forum.

Protopappas L., Sideridis A.B, (2013). The Strategy and the Progress Made on E-Government Services in the EU, conference, E-Democracy, Security, Privacy and Trust in a Digital World, vol 441 pp 192-201.

UN. (2014). United Nation E-governmetn Survey.

UN. (2014). E-Government Survey, New York.

UN. (2016). E-Government Survey. New York.

UNDP, (2010). eGovernance and ICT Usage Report for SouthEast Europe (second edition), Sarajevo.

Stojanovic, Z. (2014). Perspective for e-business in Bosnia and Herzegovina. Journal of Emerging Trends in Computing and Information Science, pp 596-602.

Stojanovic, Z. (2014). E-poslovanje”, Slobomir P

University.

\footnotetext{
${ }^{9} \mathrm{http}: / /$ www.fedzzo.com.ba

${ }^{10} \mathrm{http}: / /$ www.katastar.ba/

${ }^{11} \mathrm{http}: / /$ www.pufbih.ba/v1/

${ }^{12} \mathrm{https}: / /$ www.zdravstvo-srpske.org/home.html

${ }^{13} \mathrm{http}: / /$ www.ezkrs.net/

${ }^{14} \mathrm{https}$ ://www.poreskaupravars.org/

${ }^{15}$ www.esrpska.com
} 